\title{
Osteoprotegerin influences the bone resorption activity of osteoclasts
}

\author{
YING-XIAO FU*, JIAN-HONG GU*, YI-RAN ZHANG, XI-SHUAI TONG, HONG-YAN ZHAO, \\ YAN YUAN, XUE-ZHONG LIU, JIAN-CHUN BIAN and ZONG-PING LIU
}

College of Veterinary Medicine, Yangzhou University, Yangzhou, Jiangsu 225009, P.R. China

Received December 27, 2012; Accepted March 5, 2013

DOI: $10.3892 /$ ijmm.2013.1329

\begin{abstract}
The aim of the present study was to determine whether osteoprotegerin (OPG) influences the bone resorption activity of osteoclasts. RAW264.7 cells were induced by macrophage colony-stimulating factor $(\mathrm{M}-\mathrm{CSF})+$ receptor activator of nuclear factor- $\kappa \mathrm{B}$ ligand (RANKL) and 0,10 , 20, 50 and $100 \mathrm{ng} / \mathrm{ml}$ OPG were added into various groups in the presence of the two cytokines. The OPG treatment was continued for $24 \mathrm{~h}$. Osteoclast differentiation and activation were estimated via TRAP staining assay, TRITC-conjugated phalloidin staining, resorption activity analysis. Furthermore, the expression levels of the osteoclastic bone resorption-related genes MMP-9, cathepsin K and carbonic anhydrase II (CA II) were examined using real-time polymerase chain reaction (PCR). The data demonstrated that high concentrations of OPG could inhibit the differentiation and activation of osteoclasts. Furthermore, real-time PCR analysis illustrated that OPG decreased the expression of MMP-9 and cathepsin K in different concentrations of OPG and it decreased the expression of CA II genes at 10 and $20 \mathrm{ng} / \mathrm{ml}$ concentrations of OPG. For the time gradient study, OPG decreased the expression of MMP-9 and CA II genes but not that of the cathepsin K gene. In summary, the resorption activity of osteoclasts was suppressed by high concentrations of OPG and, at the molecular level, OPG decreased the expression of osteoclastic bone resorption-related genes.
\end{abstract}

\section{Introduction}

In higher vertebrates and mammals, the bone is constantly being remodeled in order to regulate its architecture to satisfy mechanical needs and to repair damaged tissue; it is a highly dynamic tissue. Activation of osteoclasts initiates the remode-

Correspondence to: Professor Zong-Ping Liu, College of Veterinary Medicine, Yangzhou University, 88 Daxuenanlu Road, Yangzhou, Jiangsu 225009, P.R. China

E-mail: liuzongping@yzu.edu.cn

*Contributed equally

Key words: osteoprotegerin, osteoclast, differentiation, bone resorption ling cycle, which resorbs the underlying bone tissue, followed by the activation of osteoblasts, which are responsible for the formation of new bone tissue $(1,2)$. The two processes must be tightly balanced to ensure proper bone homeostasis and calcium metabolism, and loss of this balance leads to several skeletal disorders $(3,4)$. Osteoclasts are multinucleated cells of the monocytic-macrophage lineage, and are derived from hematopoietic stem cells through a series of differentiation steps (5). Osteoclasts require cytokines, especially macrophage colony-stimulating factor (M-CSF), for their survival $(6,7)$. The receptor activator of nuclear factor $-\kappa B$ ligand (RANKL), expressed in osteoblasts and synovial fibroblasts as well as in T cells (5), represents the crucial regulator for osteoclast differentiation and activation (8). M-CSF and RANKL are essential for osteoclastogenesis in vitro (9). Simonet et al (10) previously demonstrated that osteoprotegerin (OPG) is involved in the regulation of bone density. OPG can prevent the binding of RANKL to its receptor, RANK, and blocks signaling cascade of osteoclast formation in vitro and in vivo $(11,12)$. OPG knockout mice displayed osteoporosis owing to enhanced bone resorption at local sites. The decreased activity in osteoclasts induced by exogenous OPG may improve bone mass (13).

It is well known that cathepsin K, MMP-9 and carbonic anhydrase II (CA II) genes are involved in osteoclastic bone resorption (14). Wittrant et al (15) reported that OPG exerts an overall inhibitory effect on the expression of cathepsin $\mathrm{K}$ and MMP-9 in differentiated RAW264.7 cells in a dosedependent manner. Chen et al (16) previously demonstrated that OPG inhibits the expression of CA II mRNA in mouse osteoclast-like cells. Therefore, how OPG alters the expression of cathepsin K, MMP-9 and CA II mRNA in different treatment periods to osteoclasts becomes a critical question that requires further elucidation. In this study, the effects of OPG on the bone resorption activity of osteoclasts were investigated via TRAP staining, F-actin staining, resorption activity analysis and osteoclastic bone resorption-related gene expression using RAW264.7 cells. The purpose of this study was to lay the foundations for the OPG treatment potential to abnormal osteoclast bone resorption activity.

\section{Materials and methods}

RAW264.7 cell culture. Murine monocyte/macrophage cell line RAW264.7 was obtained from the American Type Culture 
Collection (Manassas, VA, USA). It was cultured in DMEM (Gibco, USA) supplemented with 10\% FBS, $100 \mathrm{U} / \mathrm{ml}$ penicillin, $100 \mu \mathrm{g} / \mathrm{ml}$ streptomycin and $2 \mathrm{mmol} / \mathrm{l} \mathrm{L}$-glutamine. The cells were suspended in $\alpha$-MEM (containing 10\% FBS) and placed in 96-well plates for TRAP-staining, and were seeded in Corning Osteo Assay Surface (COAS; Corning Inc., USA) for F-actin staining and resorption activity analysis, respectively. After $24 \mathrm{~h}$ of incubation, the medium was changed to serum-free $\alpha$-MEM with $25 \mathrm{ng} / \mathrm{ml} \mathrm{M-CSF}+30 \mathrm{ng} / \mathrm{ml}$ RANKL (M-CSF and RANKL were obtained from Peprotech Inc., USA). For $48 \mathrm{~h}$ cultivation, 0, 10, 20, 50 and $100 \mathrm{ng} / \mathrm{ml}$ OPG (Peprotech Inc.) were added into various groups in the presence of the two cytokines, and the cells were cultured for another $24 \mathrm{~h}$.

Cell viability MTT assay. To examine the effect of OPG on cell growth, RAW264.7 cells were treated with various concentrations of OPG and cell growth was measured by an MTT assay. In brief, the cells were plated in 96-well plates in $\alpha$-MEM containing 10\% FBS and incubated for $24 \mathrm{~h}$. The medium was then changed to $\alpha$-MEM without FBS and after $48 \mathrm{~h}$ different concentrations of OPG $(0,10,20,50$ and $100 \mathrm{ng} / \mathrm{ml})$ were added to the culture for another $24 \mathrm{~h}$. At the end of the incubation, plates were washed with PBS three times, and DMEM (without FBS) containing $10 \%$ MTT solution $(0.5 \mathrm{mg} / \mathrm{ml}$ in PBS) was added to each well. After a 4-h incubation period at $37^{\circ} \mathrm{C}$, the insoluble formazan crystals formed were dissolved in $150 \mu \mathrm{l}$ of dimethyl sulfoxide (DMSO). The optical density (OD) was immediately measured at $570 \mathrm{~nm}$ using Sunrise microplate reader (Tecan, Austria).

Osteoclast differentiation from RAW264.7 cells. Osteoclast formation was measured by quantifying cells positively stained by TRAP (Acid Phosphatase Kit 387-A; SigmaAldrich, USA). TRAP staining was conducted according to the manufacturer's protocol. Under a light microscope, TRAP-positive multinucleated cells having three or more nuclei were considered as osteoclasts, and their numbers were counted in randomly selected visual fields in different areas of each well.

Filamentous $(F)$ - actin staining. RAW264.7 cells were seeded in COAS. For visualization of the actin cytoskeleton, TRITCconjugated phalloidin (Invitrogen) was employed, and was used at a concentration of $20 \mu \mathrm{mol} / \mathrm{l}$. At the end of the incubation, cells were fixed, permeabilized and stained following the manufacturer's instructions. The stained cells were observed by an inverted phase contrast fluorescence microscope (DMI 3000B; Leica) with appropriate filters.

Resorption activity analysis. The manipulation followed the COAS product protocol. In brief, at the end of cultivation, medium was aspirated completely and $10 \%$ bleach solution was added for $5 \mathrm{~min}$ of incubation. Bleach solution was removed and the wells were washed twice with $\mathrm{dH}_{2} \mathrm{O}$. The plates were allowed to air dry completely for 3-5 h. Pits appeared as individual or multiple clusters at the bottom of the wells and were visualized via an inverted phase contrast microscope. The area of resorption lacunae was measured by image analysis (Version 1.0; JEDA).

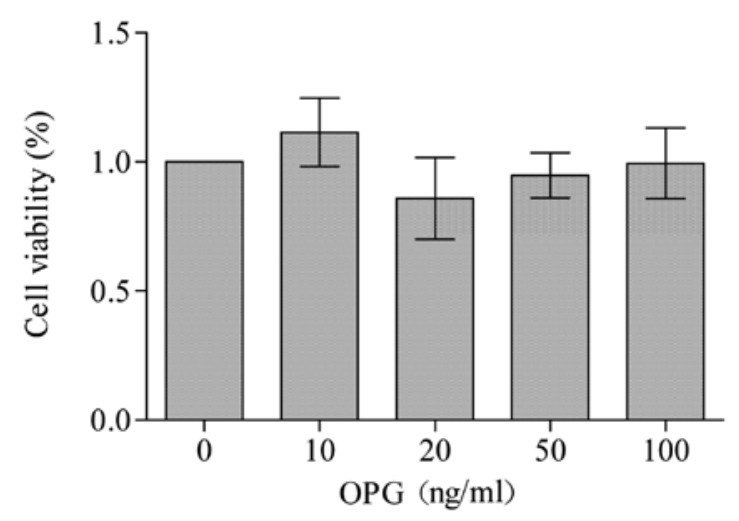

Figure 1. The effect of OPG on cell viability measured with the MTT assay. The results are expressed as the means \pm SEM.

Real-time fluorescence quantitative polymerase chain reaction (PCR) analysis. RAW264.7 cells were suspended in $\alpha$-MEM (containing 10\% FBS) and then seeded in 6 -well culture plates. After $24 \mathrm{~h}$ of cultivation, the medium was changed to serum-free $\alpha$-MEM with $25 \mathrm{ng} / \mathrm{ml}$ $\mathrm{M}-\mathrm{CSF}+30 \mathrm{ng} / \mathrm{ml} \mathrm{RANKL}$ and was maintained for $48 \mathrm{~h}$. For concentration gradient study, 0, 10, 20,50 and $100 \mathrm{ng} / \mathrm{ml}$ OPG were added into various groups in the presence of the two cytokines. The OPG treatment was continued for $30 \mathrm{~min}$, and cells were treated by M-CSF + RANKL for another $30 \mathrm{~min}$ as control groups. For the time gradient study, $100 \mathrm{ng} /$ $\mathrm{ml} \mathrm{OPG}$ were added into various groups in the presence of the two cytokines. The OPG treatment was continued for 15, 30, 60 and $120 \mathrm{~min}$, individually, and cells were treated with M-CSF + RANKL without OPG for another $15 \mathrm{~min}$ as control groups.

Total RNA was extracted at the indicated time-points. cDNA synthesis was conducted with 900 ng RNA using PrimeScript RT reagent Kit with gDNA Eraser (Takara, Japan). Real-time PCR was performed by the 7500 Real-Time PCR system (Applied Biosystems). The PCR protocol for cathepsin K, MMP-9 and CA II consisted of 40 cycles of $95^{\circ} \mathrm{C}$ for $30 \mathrm{sec}$ and $57^{\circ} \mathrm{C}$ for $1 \mathrm{~min}$. The specific sequences of the PCR primers for cathepsin K, MMP-9, CA II and GAPDH were: cathepsin $\mathrm{K}$, forward, 5'-CGC-CTG-CGG-CAT-TAC-CAA-3' and reverse, 5'-TAG-CAT-CGC-TGC-GTC-CCT-3'; MMP-9, forward, 5'-GCC-CTG-GAA-CTC-ACA-CGA-CA-3' and reverse, 5'-TTG-GAA-ACT-CAC-ACG-CCA-GAA-G-3'; CA II, forward, 5'-CAT-TAC-TGT-CAG-CAG-CGA-GCA-3' and reverse, 5'-GAC-GCC-AGT-TGT-CCA-CCA-TC-3'; GAPDH, forward, 5'-AAA-TGG-TGA-AGG-TCG-GTG-TG-3' and reverse, 5'-TGA-AGG-GGT-CGT-TGA-TGG-3'. All realtime PCR reactions were carried out at least three times, and the specificity of the PCR products was verified by melting curve analysis.

Statistical analysis. All experimental data are expressed as the means \pm standard error of the mean and all experiments were repeated in triplicate. Statistical differences between groups were evaluated by Tukey's test using SPSS ver. 17.0 software. $\mathrm{P}<0.05$ was considered to indicate statistically significant differences. 

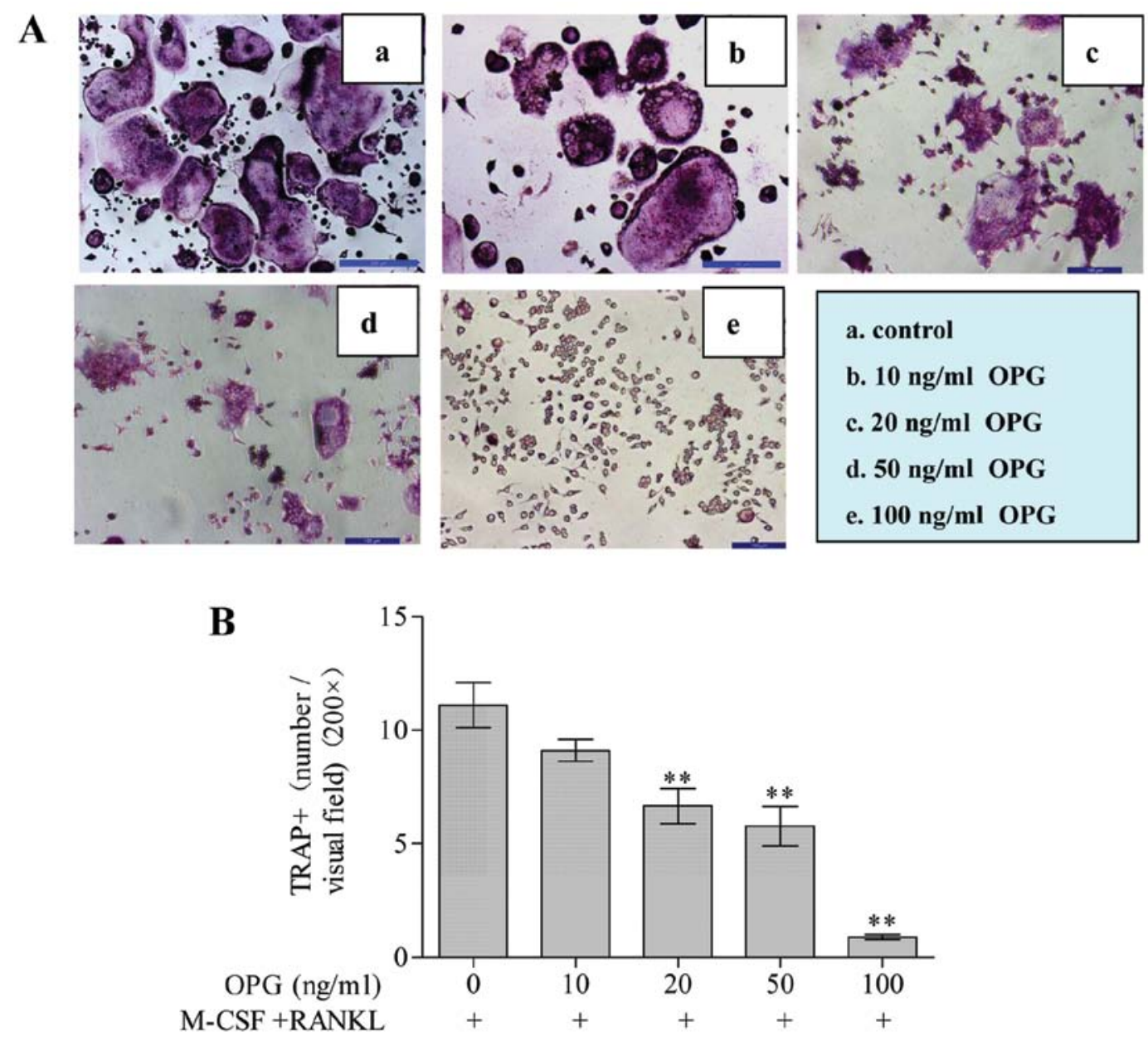

Figure 2. Inhibition of osteoclast differentiation by OPG. (A) RAW264.7 cells were suspended in $\alpha$-MEM (containing 10\% FBS) and placed in 96-well plates . After $24 \mathrm{~h}$ of incubation, the medium was changed to serum-free $\alpha$-MEM with $25 \mathrm{ng} / \mathrm{ml} \mathrm{M}-\mathrm{CSF}+30 \mathrm{ng} / \mathrm{ml} \mathrm{RANKL}$. For $48 \mathrm{~h}$ of cultivation, $0,10,20,50$ and $100 \mathrm{ng} / \mathrm{ml}$ OPG were added into various groups in the presence of the two cytokines, and the cells were cultured for another $24 \mathrm{~h}$. At the end of the incubation, cells were fixed and stained for TRAP. (B) TRAP-positive multinucleated cells (TRAP+) were counted. The results are expressed as the means \pm SEM. ${ }^{* *} \mathrm{P}<0.01$ vs. vehicle-treated cells. Original magnification, $\mathrm{x} 200$. Bar, $100 \mu \mathrm{m}$.

\section{Results}

Action of OPG on RAW264.7 cell viability. OPG did not affect the cell growth rate of RAW264.7 cells (Fig. 1), sustaining substantial viability even when used at concentrations of $100 \mathrm{ng} / \mathrm{ml}$ OPG (99.45\%). This indicated that OPG was not cytotoxic to RAW264.7 cells. Therefore, the concentrations of $0,10,20,50$ and $100 \mathrm{ng} / \mathrm{ml}$ OPG were employed in the subsequent experiments.

OPG inhibits the formation of TRAP-positive multinucleated cells. RAW264.7 cells cultured in the presence of M-CSF + RANKL for 4 days formed large mature osteoclasts with multinuclei characterized by the acquisition of mature phenotypic markers, such as TRAP (Fig. 2A). At the same time, different concentrations of OPG were added to RAW264.7 cells when stimulated with M-CSF + RANKL. The number of TRAP-positive multinucleated cells decreased with increasing OPG concentrations (Fig. 2A). OPG reduced the number of TRAP-positive multinucleated cells generated for $17.28 \pm 9.12,37.91 \pm 20.87,48.12 \pm 9.81$ and $89.71 \pm 3.15 \%$ inhibition at $10,20,50$ and $100 \mathrm{ng} / \mathrm{ml}$ concentrations, individually
(Fig. 2B). Collectively, these results indicated that OPG inhibited M-CSF + RANKL-induced osteoclastogenesis.

Effect of OPG on the F-actin rings forming in osteoclasts. M-CSF + RANKL-treated RAW264.7 cells formed large multinucleated osteoclasts with dense and smooth F-actin rings on the COAS. However, their development was inhibited by OPG. They were higher-ordered and evident around osteoclasts in the control groups and had lower concentrations in the OPG groups. Nevertheless, only F-actin clusters or belts were observed in $100 \mathrm{ng} / \mathrm{ml}$ OPG groups rather than F-actin rings (Fig. 3). These results indicated that the effect of OPG on bone resorption was due to its negative influence on the F-actin ring formation.

Effect of OPG on the resorption activity of osteoclasts. RAW264.7 cells were stimulated with M-CSF + RANKL to induce the differentiation of mature osteoclasts with boneresorbing capacity. Cavities appeared in the bottom of COAS with various shapes. The bottom of COAS was not intact and smooth in any cell group (Fig. 4A). However, OPG hindered the resorptive capacity of osteoclasts and in a dose-dependent 

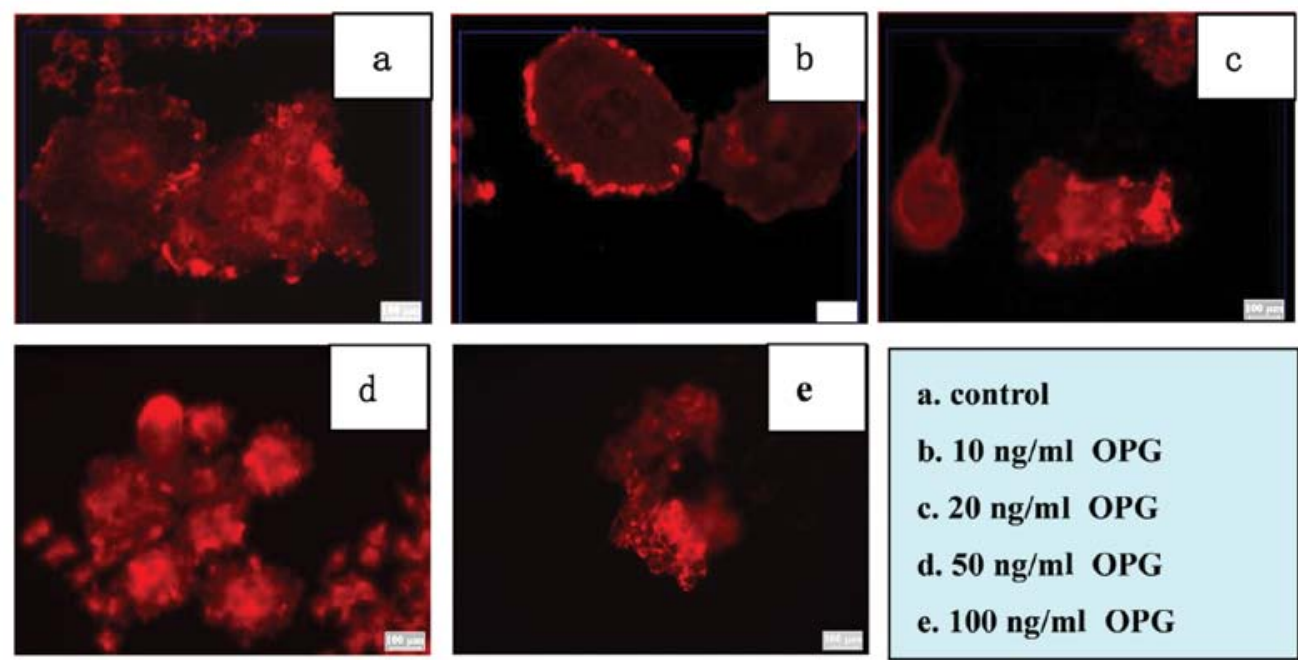
a. control
b. $10 \mathrm{ng} / \mathrm{ml}$ OPG
c. $20 \mathrm{ng} / \mathrm{ml}$ OPG
d. $50 \mathrm{ng} / \mathrm{ml}$ OPG
e. $100 \mathrm{ng} / \mathrm{ml}$ OPG

Figure 3. Suppressive effects on the sealing zone formation of OPG in M-CSF + RANKL-induced RAW264.7 cells. The Corning Osteo Assay Surface (COAS) is an inorganic crystalline calcium phosphate coating on a polystyrene plate designed to mimic in vivo bone environment. The surface is intended to facilitate surface resorption assays for osteoclasts. RAW264.7 cells were suspended in $\alpha$-MEM (containing 10\% FBS) and seeded in the COAS. After $24 \mathrm{~h}$ of incubation, the medium was changed to serum-free $\alpha$-MEM with $25 \mathrm{ng} / \mathrm{ml}$ M-CSF $+30 \mathrm{ng} / \mathrm{ml} \mathrm{RANKL}$. For $48 \mathrm{~h}$ of cultivation, 0, 10, 20, 50 and $100 \mathrm{ng} / \mathrm{ml}$ OPG were added into various groups in the presence of the two cytokines, and the cells were cultured for another $24 \mathrm{~h}$. At the end of the incubation, cells were fixed and stained for TRITC-phalloidin. Original magnification, $\mathrm{x} 400$. Bar, $100 \mu \mathrm{m}$.

A
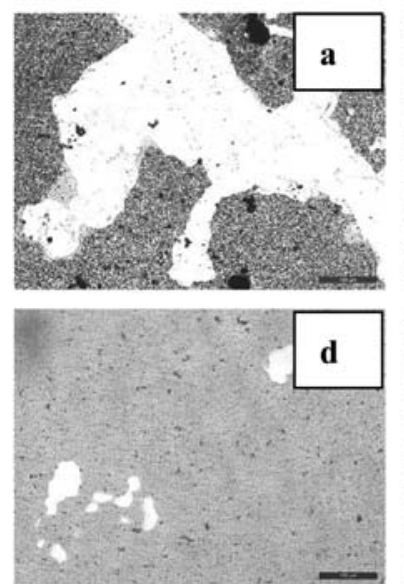
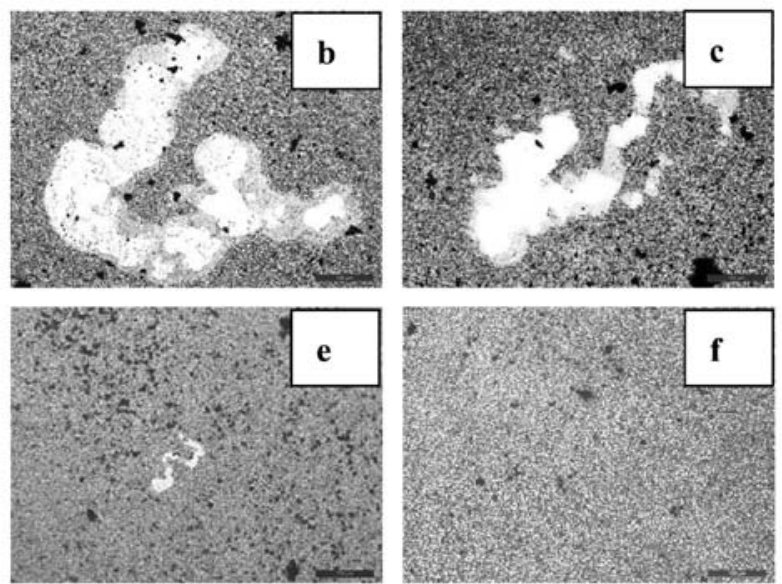

B

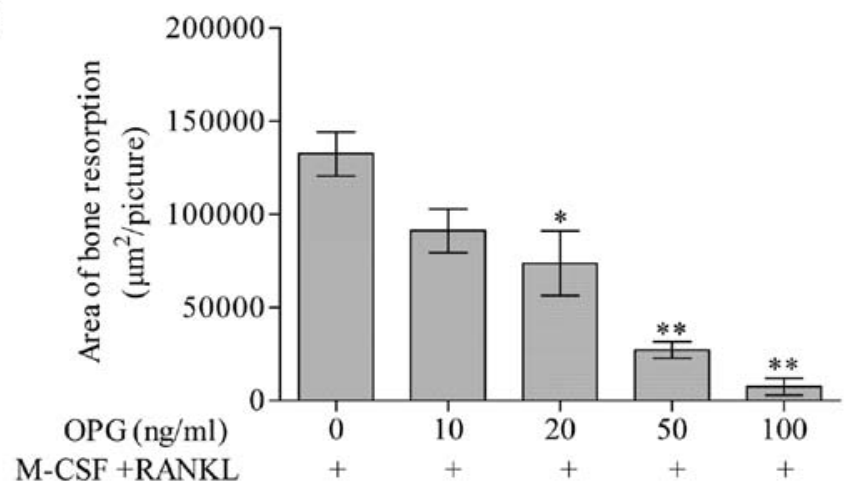

Figure 4. Inhibition of osteoclast resorption activity by OPG. (A) RAW264.7 cells were seeded in the COAS, cultured in the presence of M-CSF $(25 \mathrm{ng} / \mathrm{ml})+$ RANKL (30 ng/ml) and with the indicated concentration of OPG (a) control; (b) $10 \mathrm{ng} / \mathrm{ml}$; (c) $20 \mathrm{ng} / \mathrm{ml}$; (d) $50 \mathrm{ng} / \mathrm{ml}$; (e) $100 \mathrm{ng} / \mathrm{ml}$ for the final $24 \mathrm{~h}$ in the presence of the two cytokines, and (f) no cell. At the end of the incubation, pit resorption areas were measured. Original magnification, $\mathrm{x} 200$. Bar, $100 \mu \mathrm{m}$. (B) The histogram represents the volume of pit resorption. The results are expressed as the means $\pm \mathrm{SEM}$. "P<0.05, ${ }^{* *} \mathrm{P}<0.01$ vs. control groups.

manner (Fig. 4B). The volume of resorption lacunae was significantly less in M-CSF + RANKL $+20,50$ and $100 \mathrm{ng} / \mathrm{ml}$ OPG groups than in the control groups $(\mathrm{P}<0.05)$. OPG inhib- ited the total area of resorption lacunae with $30.23 \pm 16.90$, $44.35 \pm 21.07,78.61 \pm 9.16$ and $94.60 \pm 5.88 \%$ at $10,20,50$ and $100 \mathrm{ng} / \mathrm{ml}$ concentrations, individually. 

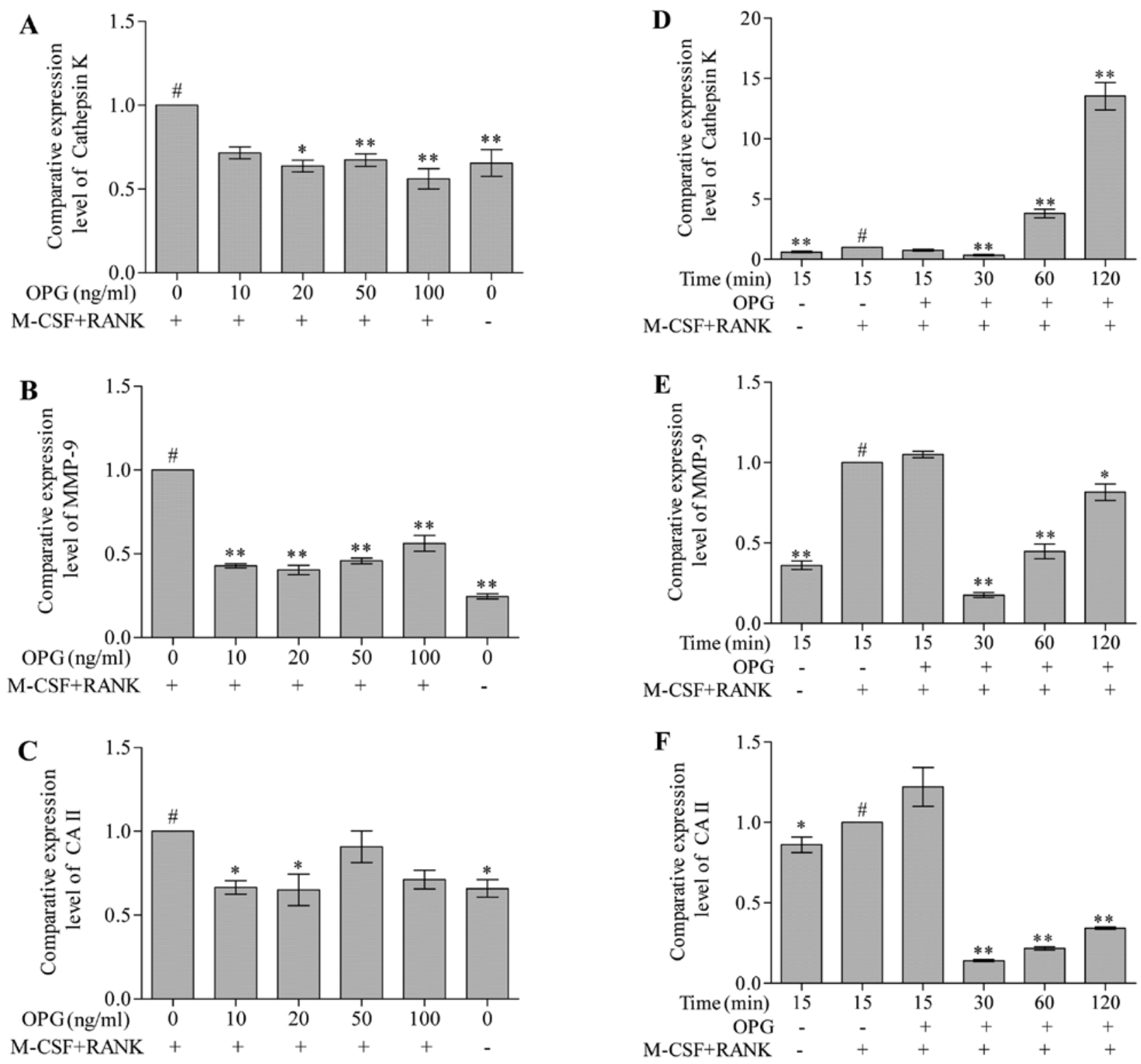

Figure 5. Effect of OPG on the expression of the MMP-9, cathepsin K and CA II genes. RAW264.7 cells were suspended in $\alpha$-MEM (containing 10\% FBS) and then seeded in 6-well culture plates. After $24 \mathrm{~h}$ of cultivation, the medium was changed to serum-free $\alpha$-MEM with $25 \mathrm{ng} / \mathrm{ml} \mathrm{M-CSF}+30 \mathrm{ng} / \mathrm{ml} \mathrm{RANKL}$ and sustained for $48 \mathrm{~h}$. (A-C) For the concentration gradient study, 0, 10, 20, 50 and $100 \mathrm{ng} / \mathrm{ml} \mathrm{OPG}$ were added into various groups in the presence of the two cytokines. The OPG treatment was continued for $30 \mathrm{~min}$, and cells were treated with M-CSF + RANKL for another 30 min as control groups. The mRNA expression levels of MMP-9, cathepsin K and CA II genes were determined by real-time PCR and compared with that of GAPDH. (D-F) For time gradient study, $100 \mathrm{ng} / \mathrm{ml}$ OPG were added into various groups in the presence of the two cytokines. The OPG treatment was continued for 15,30,60 and 120 min, individually, and cells were treated with M-CSF + RANKL without OPG for another $15 \mathrm{~min}$ as control groups. At the indicated time-points, mRNA expression levels of MMP-9, cathepsin K and CA II genes were measured by real-time PCR. The results are expressed as the means \pm SEM. ${ }^{* *} \mathrm{P}<0.01,{ }^{*} \mathrm{P}<0.05$ vs. control groups $(\#)$.

Regulation of cathepsin K, MMP-9, CA II mRNA expression in M-CSF + RANKL-induced osteoclast cells by OPG. The production of cathepsin K, MMP-9 and CA II gene expression for bone resorption by osteoclasts was monitored by real-time PCR. For concentration gradient study, expression of the three genes in cells cultured without M-CSF + RANKL were all significantly lower than in control groups $(\mathrm{P}<0.05)$. Expression of cathepsin K, MMP-9 mRNA in the OPG groups was statistically significantly lower than in control groups $(\mathrm{P}<0.01)$. OPG decreased the expression of cathepsin K mRNA 0.28 \pm 0.06 , $0.36 \pm 0.06,0.33 \pm 0.06,0.44 \pm 0.11$-fold, it decreased the expression of MMP-9 mRNA $0.57 \pm 0.02,0.60 \pm 0.05,0.54 \pm 0.03$, $0.44 \pm 0.08$-fold at $10,20,50$ and $100 \mathrm{ng} / \mathrm{ml}$ concentrations, respectively, and it decreased the expression of CA II mRNA $0.34 \pm 0.07,0.35 \pm 0.16$-fold at 10 and $20 \mathrm{ng} / \mathrm{ml}$ concentrations, respectively. However, the expression of CA II mRNA in the 50 and $100 \mathrm{ng} / \mathrm{ml}$ concentration groups was not significantly different to the control groups (Fig. 5A-C). For time gradient study, after OPG was added, expression of the MMP-9, cathepsin $\mathrm{K}$ and CA II genes in cells cultured without any exogenous cytokine for another $15 \mathrm{~min}$ were all significantly lower than in control groups $(\mathrm{P}<0.05)$. Furthermore, expression of the cathepsin K, MMP-9 and CA II genes in cells cultured with M-CSF + RANKL plus OPG for $15 \mathrm{~min}$ were not significantly different compared to their control groups, respectively. This demonstrated that OPG seldom affected 
the expression of MMP-9, cathepsin K and CA II mRNA in RAW264.7 cells in a short period. When treated with OPG for $30 \mathrm{~min}$, all three significantly decreased $(\mathrm{P}<0.01)$, demonstrating that OPG inhibits the expression of the three genes the most at this time-point. Expression of MMP-9 and CA II genes was significantly lower than in the control groups from 30 to $120 \mathrm{~min}$ via OPG treatment $(\mathrm{P}<0.05)$. OPG decreased the expression of MMP-9 mRNA $0.82 \pm 0.03,0.55 \pm 0.08$, $0.18 \pm 0.09$-fold and it decreased the expression of CA II mRNA $0.86 \pm 0.01,0.78 \pm 0.02,0.66 \pm 0.01$-fold, at 30, 60 and $120 \mathrm{~min}$, respectively (Fig. 5D-F). However, the expression of MMP-9 and CA II mRNA increased as the effect of OPG declined. This indicated that OPG still exerted inhibitory effects, albeit weaker, on two of them. The expression of cathepsin K mRNA was significantly increased with the OPG treatment for 60 to $120 \min (\mathrm{P}<0.01)$ (Fig. 5E).

\section{Discussion}

The hallmark of osteoclasts is their unique ability to resorb mineralized calcium apatite or carbonate substrates such as bone, dentin or nacre (17). In the osteoclast resorption process, F-actin ring formation is critical (18). F-actin is first organized into podosome (19), osteoclasts exhibit two different actin cytoskeleton organizations according to their substratum. They form canonical podosomes on non-mineralized substrates while they form sealing zones on mineralized extracellular matrices $(17,20)$. Podosome clusters are built in early osteoclasts, which evolve into dynamic rings at intermediate stages and form peripheral podosome belts in mature cells by fusion of the rings (21). When the osteoclasts are polarized, they exhibit sealing zones and exert bone resorption activity $(17,20)$. In sealing zones, the F-actin filament builds attachment ring structures, thus, in activated osteoclasts, compact ring structures were usually observed when F-actin was stained (22). The RAW264.7 cell line is a recognized pre-osteoclast model and has been extensively employed in osteoclast studies $(2,15)$. In the present study, RAW264.7 cells were cultured in the presence of M-CSF, RANKL established functional F-actin rings and possessed bone resorption ability, whereas OPG impeded their formation. Only F-actin clusters or belts were found in high concentration OPG groups. Accordingly, the resorption activity of osteoclasts was weakened by OPG.

Degradation of mineralized bone matrix by osteoclasts includes dissolution of crystalline hydroxyapatite and proteolytic cleavage of the organic matrix. Before proteolytic enzymes can reach and degrade collagenous bone matrix, hydroxyapatite crystals must be dissolved (23). CA II is critical not only in bone resorption but also in osteoclast differentiation (24); it provides the proton source for extracellular acidification by $\mathrm{H}^{+}$-ATPase and the $\mathrm{HCO}^{-}$source for the $\mathrm{HCO}^{-} / \mathrm{Cl}^{-}$exchanger which is the major transporter for maintenance of normal intracellular $\mathrm{pH}$ (25-28). After the degradation of the hydroxyapatite crystals, organic matrix is subsequently dissolved. Two major classes of proteolytic enzymes are involved, i.e., the cysteine proteinase family (such as cathepsin K) and the MMP family (29).

In this study, the expression of MMP-9, cathepsin K and CA II mRNA in RAW264.7 cells was induced by M-CSF + RANKL, and the results indicated that M-CSF + RANKL may induce bone resorption by osteoclasts via increased CA II, cathepsin K and MMP-9 production. However, the expression levels of cathepsin K and MMP-9 mRNA were all inhibited by different concentrations of OPG. The OPG inhibitory effects on the two gene expressions were similar to those previously reported by Wittrant et al (15). The expression of CA II mRNA was significantly decreased by 10 and $20 \mathrm{ng} / \mathrm{ml} \mathrm{OPG}$, however,

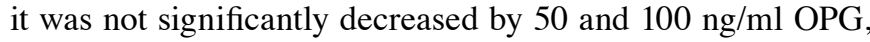
contrary to the report of Chen et al (16). This finding warrants further study. For the time gradient study, M-CSF + RANKL significantly enhanced their expression in the short term, whereas OPG markedly decreased their expression following treatment for $30 \mathrm{~min}$. However, they all decreased at first but subsequently increased. The study by Wittrant et al (15) proved that the RANK-RANKL complex may represent the OPG receptor at the RAW264.7 cell surface. In the OPG treatment course, its inhibitory effect on the expression of MMP-9 and CA II mRNA weakened, as previously mentioned, and the influence of OPG lessened afterwards. Of note, the expression of cathepsin K mRNA was significantly raised with the cell cultivation. Cathepsin $\mathrm{K}$ is selectively expressed in osteoclasts and plays a critical role in the bone resorption. It secretes from the cell as an inactive form and then converts to its mature active form by proteolytic cleavage of the prodomain at low $\mathrm{pH}$ in vivo (30). The $\mathrm{pH}$ value of the cell culture environment gradually declined in the incubation period. First, a lot of acidic products were metabolized by cells, the $\mathrm{pH}$ value of medium was dropped. Second, as the initiation of osteoclastic resorption, the evident production of CA II contributed to the acidity of cell ambience. Thus, the expression and activity of cathepsin $\mathrm{K}$ markedly increased.

In conclusion, the resorption activity of osteoclasts was suppressed by high concentrations of OPG. Furthermore, at the molecular level, OPG decreased the expression of osteoclastic bone resorption-related genes.

\section{Acknowledgements}

This study was supported by the National Natural Science Foundation of China (nos. 30972229 and 31172373) and a project Funded by the Priority Academic Program Development of Jiangsu Higher Education Institutions and the Graduate Innovation Project of Jiangsu Province.

\section{References}

1. Li J, Sarosi I, Yan XQ, Morony S, Capparelli C, Tan HL, McCabe S, Elliott R, Scully S, Van G, Kaufman S, Juan SC, Sun Y, Tarpley J, Martin L, Christensen K, McCabe J, Kostenuik P, Hsu H, Fletcher F, Dunstan CR, Lacey DL and Boyle WJ: RANK is the intrinsic hematopoietic cell surface receptor that controls osteoclastogenesis and regulation of bone mass and calcium metabolism. Proc Natl Acad Sci USA 97: 1566-1571, 2000.

2. Brinkmann J, Hefti T, Schlottig F, Spencer ND and Hall H: Response of osteoclasts to titanium surfaces with increasing surface roughness: an in vitro study. Biointerphases 7: 34, 2012.

3. Anderegg F, Geblinger D, Horvath P, Charnley M, Textor M, Addadi L and Geiger B: Substrate adhesion regulates sealing zone architecture and dynamics in cultured osteoclasts. PloS One 6: e28583, 2011.

4. Shibata K, Yoshimura Y, Kikuiri T, Hasegawa T, Taniguchi Y, Deyama Y, Suzuki Ka and Iida J: Effect of the release from mechanical stress on osteoclastogenesis in RAW264.7 cells. Int J Mol Med 28: 73-79, 2011. 
5. Shu G, Yamamoto K and Nagashima M: Differences in osteoclast formation between proximal and distal tibial osteoporosis in rats with adjuvant arthritis: inhibitory effects of bisphosphonates on osteoclasts. Mod Rheumatol 16: 343-349, 2006

6. Suda T, Udagawa N, Nakamura I, Miyaura C and Takahashi N: Modulation of osteoclast differentiation by local factors. Bone 17 (Suppl 2): 87S-91S, 1995.

7. Glantschnig H, Fisher JE, Wesolowski G, Rodan GA and Reszka AA: M-CSF, TNFalpha and RANK ligand promote osteoclast survival by signaling through mTOR/S6 kinase. Cell Death Differ 10: 1165-1177, 2003.

8. Nemeth K, Schoppet M, Al-Fakhri N, Helas S, Jessberger R Hofbauer LC and Goettsch C: The role of osteoclast-associated receptor in osteoimmunology. J Immunol 186: 13-18, 2011.

9. Mancino AT, Klimberg VS, Yamamoto M, Manolagas SC and Abe E: Breast cancer increases osteoclastogenesis by secreting M-CSF and upregulating RANKL in stromal cells. J Surg Res 100: 18-24, 2001.

10. Simonet WS, Lacey DL, Dunstan CR, Kelley M, Chang MS, Lüthy R, Nguyen HQ, Wooden S, Bennett L, Boone T, Shimamoto G, DeRose M, Elliott R, Colombero A, Tan HL, Trail G, Sullivan J, Davy E, Bucay N, Renshaw-Gegg L, Hughes TM, Hill D, Pattison W, Campbell P, Sander S, Van G, Tarpley J, Derby P, Lee R and Boyle WJ: Osteoprotegerin: a novel secreted protein involved in the regulation of bone density. Cell 89: 309-319, 1997

11. Roodman GD: Cell biology of the osteoclast. Exp Hematol 27: 1229-1241, 1999.

12. Hsu H, Lacey DL, Dunstan CR, Solovyev I, Colombero A, Timms E, Tan HL, Elliott G, Kelley MJ, Sarosi I, Wang L, Xia XZ, Elliott R, Chiu L, Black T, Scully S, Capparelli C, Morony S, Shimamoto G, Bass MB and Boyle WJ: Tumor necrosis factor receptor family member RANK mediates osteoclast differentiation and activation induced by osteoprotegerin ligand. Proc Nat Acad Sci USA 96: 3540-3545, 1999.

13. Makihira S, Mine Y, Nikawa H, Shuto T, Kosaka E, Sugiyama M and Hosokawa R: Immobilized-OPG-Fc on a titanium surface inhibits RANKL-dependent osteoclast differentiation in vitro J Mater Sci Mater Med 21: 647-653, 2010.

14. Vaananen HK, Liu YK, Lehenkari P and Uemara T: How do osteoclasts resorb bone? Mater Sci Eng C 6: 205-209, 1998.

15. Wittrant Y, Theoleyre S, Couillaud S, Dunstan C, Heymann D and Rédini F: Relevance of an in vitro osteoclastogenesis system to study receptor activator of $\mathrm{NF}-\kappa \mathrm{B}$ ligand and osteoprotegerin biological activities. Exp Cell Res 293: 292-301, 2004

16. Chen J, He JQ, Zhen SY and Huang LQ: OPG inhibits gene expression of RANK and CAII in mouse osteoclast-like cell. Rheumatol Int 32: 3993-3998, 2012.

17. Saltel F, Chabadel A, Bonnelye E and Jurdic P: Actin cytoskeletal organisation in osteoclasts: a model to decipher transmigration and matrix degradation. Eur J Cell Biol 87: 459-468, 2008.
18. Lee JW, Mase N, Yonezawa T, Seo HJ, Jeon WB, Cha BY, Nagai K and Woo JT: Palmatine attenuates osteoclast differentiation and function through inhibition of receptor activator of nuclear factor- $\kappa \mathrm{b}$ ligand expression in osteoblast cells. Biol Pharm Bull 33: 1733-1739, 2010.

19. Ye S, Fowler TW, Pavlos NJ, Ng PY, Liang K, Feng Y, Zheng M, Kurten R, Manolagas SC and Zhao H: LIS1 regulates osteoclast formation and function through its interactions with dynein/ dynactin and Plekhm1. PloS One 6: e27285, 2011.

20. Jurdic P, Saltel F, Chabadel A and Destaing O: Podosome and sealing zone: specificity of the osteoclast model. Eur J Cell Biol 85: 195-202, 2006.

21. Destaing O, Saltel F, Geminard JC, Jurdic P and Bard F: Podosomes display actin turnover and dynamic self-organization in osteoclasts expressing actin-green fluorescent protein. Mol Biol Cell 14: 407-416, 2003.

22. Meng B, Yang X, Chen Y, Zhai J and Liang X: Effect of titanium particles on osteoclast activity in vitro. Mol Med Rep 3: $1065-1069,2010$

23. Vaananen HK, Zhao H, Mulari M and Halleen JM: The cell biology of osteoclast function. J Cell Sci 113: 377-381, 2000.

24. Lehenkari P, Hentunen TA, Laitala-Leinonen T, Tuukkanen J and Vaananen HK: Carbonic anhydrase II plays a major role in osteoclast differentiation and bone resorption by effecting the steady state intracellular $\mathrm{pH}$ and $\mathrm{Ca}^{2+}$. Exp Cell Res 242: 128-137, 1998.

25. Gu JH, Liu JD, Shen Y and Liu ZP: Effects of RANKL, osteoprotegerin, calcium and phosphorus on survival and activation of Muscovy duck osteoclasts in vitro. Vet J 181: 321-325, 2009.

26. Teitelbaum SL, Tondravi MM and Ross FP: Osteoclasts, macrophages, and the molecular mechanisms of bone resorption. J Leukoc Biol 61: 381-388, 1997.

27. Rousselle AV and Heymann D: Osteoclastic acidification pathways during bone resorption. Bone 30: 533-540, 2002.

28. Riihonen R, Supuran CT, Parkkila S, Pastorekova S, Vaananen HK and Laitala-Leinonen T: Membrane-bound carbonic anhydrases in osteoclasts. Bone 40: 1021-1031, 2007.

29. Kusano K, Miyaura C, Inada M, Tamura T, Ito A, Nagase H, Kamoi K and Suda T: Regulation of matrix metalloproteinases (MMP-2, -3, -9, and -13) by interleukin-1 and interleukin- 6 in mouse calvaria: association of MMP induction with bone resorption. Endocrinology 139: 1338-1345, 1998.

30. Yang J, Shang GD and Zhang YQ: Study of a novel antiosteoporosis screening model targeted on cathepsin K. Biomed Environ Sci 17: 273-280, 2004. 